\title{
Mobilizing Early-Stage Investments for an Innovation-Led Sustainability Transition
}

\author{
Friedemann Polzin, Mark Sanders, and Ulrika Stavlöt
}

\subsection{INTRODUCTION}

The estimated required investments into technologies to make the transition toward a sustainable economy are enormous (IEA 2016; New Climate Economy 2014). The 2008-2014 global recession has rapidly deteriorated the financial position of the public sector and lowered the risk appetite of the private sector (Block and Sandner 2009; Cowling et al. 2016). Technologically there seem to be no barriers to address the challenge (Iyer et al. 2015). But the vast resources of the private sector must be engaged to make a timely transition (Perez 2013). Unfortunately, private investment is falling short of target levels year after year. Apparently, the business case for green tech investments is not yet profitable enough. Many have therefore argued that the transition needs significant further innovation and improvement to existing technology (Negro et al. 2012).

F. Polzin $(\bowtie) \bullet$ M. Sanders

Utrecht School of Economics and Sustainable Finance Lab, Utrecht, The Netherlands

U. Stavlöt

Forum for Reforms, Entrepreneurship and Sustainability (FORES), Stockholm, Sweden

(C) The Author(s) 2018

T. Walker et al. (eds.), Designing a Sustainable Financial System, Palgrave Studies in Sustainable Business In Association with Future Earth, https://doi.org/10.1007/978-3-319-66387-6_13 
In the literature it is increasingly recognized that new, small firms and, in particular, (high-impact) entrepreneurship are important drivers of transformational innovation 'creative destruction' processes $^{1}$ (Schumpeter 1934). This is also true for the transition to a green economy (Bocken 2015; Ghosh and Nanda 2010; Marcus et al. 2013). Green entrepreneurs face barriers related to green innovation and the nature of entrepreneurship (start-ups) in general (Foxon and Pearson 2008; Hockerts and Wüstenhagen 2010).

But innovative entrepreneurship requires investment of a particular kind. It is not the debt finance that banks and institutional investors can provide, but rather private (equity) investment that promotes early-stage ventures with the potential to transform a sector. Policies should therefore aim to leverage the public funds available to mobilize private (equity) investment on an unprecedented scale (Jefferson 2008; Mathews et al. 2010; Polzin 2017). Increasing the availability of equity for early-stage green tech experimentation will spur the transition to sustainability but will also increase the diversity of the financial sector and thereby enhance stability and increase resilience of financial markets against shocks (Migendt et al. 2017; Polzin et al. 2017a; Szabó and Jäger-Waldau 2008). Increasing equity investment in green tech venturing would therefore be both urgent and desirable.

Policy makers can choose from a variety of options to mobilize private investment in green entrepreneurship, ranging from technology-push to demand-pull mechanisms or more systemic instruments (Bürer and Wüstenhagen 2009; Olmos et al. 2012; Polzin 2017). Researchers have highlighted certain demand-pull instruments (e.g. feed-in tariffs) as suitable for the renewable energy sector (e.g. Bürer and Wüstenhagen 2009; Criscuolo and Menon 2015), whereas others stressed their shortcomings and argued for more research and development (R\&D) and innovationbased policies (e.g. Hoppmann et al. 2013; Kenney and Hargadon 2012). Where these papers develop strong arguments for specific policy interventions, however, the perspective of the agents these interventions aim to influence is often ignored or neglected (Georgallis and Durand 2017). Hence this chapter aims at understanding policy making from an investor and entrepreneur perspective, which is crucial for any policy that hopes to effectively leverage public funds and mobilize private capital to accelerate a transition to sustainability (Criscuolo and Menon 2015; Mazzucato 2013a; Polzin 2017; Polzin et al. 2016).

The remainder of the chapter is organized as follows: In Sect. 13.2 we depict policy measures to address finance challenges of early-stage green tech ventures. In Sect. 13.3 we present our empirical approach including research context and methods. In Sect. 13.4 we discuss from the investors' 
and entrepreneurs' point of view how informed policy design might overcome the problems we have identified. Section 13.5 concludes.

\subsection{Previous Research: Policy Measures for Promoting GreEn Venturing}

Barriers to green tech entrepreneurship relate first to the nature of the underlying technologies such as increased technological uncertainty. Second, these innovations face a high regulatory dependency. Third, these early-stage technologies typically have an inferior cost position due to the liabilities of smallness and newness (Foxon and Pearson 2008; Polzin et al. 2016). All this causes especially financial constraints limiting the diffusion of untried and untested products, missing track record and facing high risk of bankruptcy (Bocken 2015; Shepherd and Patzelt 2011). Hence, small, experimental ventures are mostly not bankable (O'Sullivan 2006). Specialized equity investors can deal with this high risk/return profile. However there are only few, their business model is not easily scalable, and it only fits the rapidly growing ventures (Dosi 1990; Mazzucato 2013b; Perez 2002). In addition, regulatory responses to reduce risk appetite in the financial industry in the aftermath of the financial crisis of 2008 hit early-stage equity investors hard (Demirel and Parris 2015; Migendt et al. 2017). Consequently, finance streams for risky green tech ventures have dried up.

The suboptimal allocation of entrepreneurial capital has been discussed by Lerner $(2009,2010)$ among others and requires policy makers to act. Achieving an innovation-led sustainability transition based on green technologies in due time justifies policy intervention on a larger scale (Bocken 2015; Bürer and Wüstenhagen 2009; Mazzucato 2013b). This strand of research stresses the need for a holistic view on how market actors behave when policy makers are attempting to facilitate the entrepreneurial and venture capital sector (Lerner 2009). According to Lerner (2010), a frequent shortcoming of public initiatives aimed at supporting venture capital markets has been impatience, as innovation needs a more long-term perspective. Mazzucato (2013b) and others (e.g. Criscuolo and Menon 2015) argue that the emergence of (green) innovative ventures and technologies requires policies directed at companies as well as at the investors and the entrepreneurs to be successful. Finally, policy makers should take a portfolio approach and exercise a high level of tolerance for failures that is not very natural to them (Weber and Rohracher 2012).

Still the literature to date remains rather vague on how exactly the more patient and risk-tolerant policy maker could then help investors and 
Table 13.1 Policies to mobilize early-stage finance

\begin{tabular}{|c|c|c|c|}
\hline Policy approach & Category & Examples & Sources \\
\hline \multirow{3}{*}{$\begin{array}{l}\text { Innovation policy } \\
\text { (technology } \\
\text { push) }\end{array}$} & \multirow{2}{*}{$\begin{array}{l}\text { Fiscal and } \\
\text { financial } \\
\text { incentives }\end{array}$} & R\&D subsidies & $\begin{array}{l}\text { Olmos et al. (2012), Veugelers } \\
(2012)\end{array}$ \\
\hline & & R\&D tax credits & $\begin{array}{l}\text { Acemoglu et al. (2012), } \\
\text { Olmos et al. (2012) }\end{array}$ \\
\hline & $\begin{array}{l}\text { Systemic } \\
\text { instruments }\end{array}$ & $\begin{array}{l}\text { Research infrastructure } \\
\text { and incubators }\end{array}$ & $\begin{array}{l}\text { Kenney and Hargadon (2012, } \\
2014)\end{array}$ \\
\hline \multirow[t]{10}{*}{$\begin{array}{l}\text { Innovation policy } \\
\text { (market pull) }\end{array}$} & $\begin{array}{l}\text { Market-based } \\
\text { incentives }\end{array}$ & $\begin{array}{l}\text { GHG emission trading } \\
\text { system }\end{array}$ & Acemoglu et al. (2012) \\
\hline & \multirow{6}{*}{$\begin{array}{l}\text { Fiscal and } \\
\text { financial } \\
\text { incentives }\end{array}$} & $\begin{array}{l}\text { Cash rebates and } \\
\text { subsidies }\end{array}$ & $\begin{array}{l}\text { Bürer and Wüstenhagen } \\
(2009)\end{array}$ \\
\hline & & $\begin{array}{l}\text { Direct investments } \\
\text { (into complementary } \\
\text { assets) }\end{array}$ & Henriot (2013) \\
\hline & & $\begin{array}{l}\text { Co-investing (into } \\
\text { companies) }\end{array}$ & Mazzucato and Penna (2016) \\
\hline & & $\begin{array}{l}\text { Loans and loan } \\
\text { guarantees }\end{array}$ & Olmos et al. (2012) \\
\hline & & Tax incentives & Barradale $(2010)$ \\
\hline & & Feed-in tariffs & $\begin{array}{l}\text { Criscuolo and Menon (2015), } \\
\text { Haley and Schuler (2011) }\end{array}$ \\
\hline & \multirow[t]{2}{*}{$\begin{array}{l}\text { Systemic } \\
\text { instruments }\end{array}$} & Public procurement & $\begin{array}{l}\text { Edquist and Zabala- } \\
\text { Iturriagagoitia }(2012)\end{array}$ \\
\hline & & $\begin{array}{l}\text { Networking and } \\
\text { conferences }\end{array}$ & Gompers and Lerner (2001) \\
\hline & $\begin{array}{l}\text { Regulatory } \\
\text { measures }\end{array}$ & $\begin{array}{l}\text { Product standards and } \\
\text { regulation }\end{array}$ & $\begin{array}{l}\text { Bürer and Wüstenhagen } \\
\text { (2009), Polzin et al. (2015) }\end{array}$ \\
\hline \multirow[t]{4}{*}{$\begin{array}{l}\text { Framework con- } \\
\text { ditions for } \\
\text { VC/PE }\end{array}$} & Regulation & $\begin{array}{l}\text { Capital market devel- } \\
\text { opment (exit } \\
\text { possibilities) }\end{array}$ & $\begin{array}{l}\text { Bottazzi and Rin (2002), } \\
\text { Da Rin et al. (2006), Lerner } \\
\text { (2010) }\end{array}$ \\
\hline & $\begin{array}{l}\text { Fiscal and } \\
\text { financial } \\
\text { incentives }\end{array}$ & Tax policy & $\begin{array}{l}\text { Keuschnigg and Nielsen } \\
(2003,2006)\end{array}$ \\
\hline & \multirow[t]{2}{*}{$\begin{array}{l}\text { Systemic } \\
\text { instruments }\end{array}$} & Bankruptcy legislation & $\begin{array}{l}\text { Cumming (2011), Lerner } \\
(2002)\end{array}$ \\
\hline & & $\begin{array}{l}\text { Labor-market } \\
\text { regulation }\end{array}$ & Lerner and Tåg (2013) \\
\hline
\end{tabular}

entrepreneurs come together more successfully. In general, policy makers can take three approaches to addressing the early-stage financing problem for green tech (Migendt et al. 2017) (see Table 13.1). First, to address the underinvestment in the very uncertain early stages of the innovation cycle, 
policy makers could support firms with $\mathrm{R} \& \mathrm{D}$ grants and prizes to reduce the need for external capital provided by investors in this stage (Olmos et al. 2012; Veugelers 2012). Similarly, directed tax credits reduce the tax burden on profit for early-stage investors (Acemoglu et al. 2012; Olmos et al. 2012). To complement these efforts and push technology from invention to commercialization and market introduction, scholars have suggested making public investments in research infrastructure dedicated to research on green technologies (Kenney and Hargadon 2012, 2014). But of course, these interventions all weigh heavily on an already strained government budget.

Second, there is the demand-pull perspective. Under the efficient capital markets hypothesis, all that is needed to promote investment is to remove barriers to free capital market flows. Then investors will automatically allocate their funds to profitable green tech ventures. Environmental, energy and climate economists therefore argue that market prices should drive the innovation process as a first-best solution. But then market prices need to be adjusted to incorporate both innovation-related and sustainability-related externalities (Acemoglu et al. 2012). This is complicated. One could internalize environmental externalities, for example, by establishing a greenhouse gas emission tax or trading system (Fischer and Newell 2008), but these instruments are not suited for internalizing the positive innovation externalities also. However, as a global and effective emission trading system is not (yet) put in place, second-best solutions from the environmental externalities perspective could target specific characteristics of green tech innovations to support their invention, commercialization and diffusion (Foxon and Pearson 2008; Polzin 2017; Polzin et al. 2016).

To bring technologies from invention into market diffusion, policy makers also have a range of instruments at their disposal (Bürer and Wüstenhagen 2009; Hoppmann et al. 2013; Polzin 2017; Veugelers 2012). Consumers could be incentivized to buy green tech products such as electric vehicles through, for example, cash or tax rebates and subsidies. That increases sales and market growth for the producer-a focal point for the early-stage investor (Bürer and Wüstenhagen 2009). More directly, governments could also follow a mission-oriented public procurement strategy, hence increasing market demand and reducing costs for novel green tech products (Edquist and Zabala-Iturriagagoitia 2012). Other instruments include public loans or loan guarantees for growing ventures (Olmos et al. 2012), although these received criticism for allowing small ventures to be overfunded (Kenney and Hargadon 2012, 2014).

Reducing risks for the private investor associated with the commercialization and scale-up phases (i.e. establishing a production line and delivering 
the product at high quality and in large quantities) is one way of augmenting specialized equity funding. Fiscal incentives such as the production tax credit prove to be effective (Barradale 2010). More directly, co-investing from public sources such as state investment banks into green tech companies (Mazzucato and Penna 2016) and public investments into complementary assets such as electric vehicle charging infrastructure or transmission grids also overcome financial barriers (Henriot 2013).

Especially relating to the electricity sector, feed-in tariffs and renewable portfolio standards (an obligatory share of renewable in total production) are also argued to have a positive influence on early-stage investments. Whereas the former are more conducive to less mature technologies as they provide for stable cash flows, the latter favor mature technologies due to the element of competition to supply the renewable energy capacity at the lowest price (Bürer and Wüstenhagen 2009; Criscuolo and Menon 2015; Haley and Schuler 2011).

Third, policy makers can also try to increase the supply of funding. For example, they may change the framework conditions for early-stage $\mathrm{VC} / \mathrm{PE}$ investments in general. Increasing the functioning of equity capital markets will allow investors to sell the companies they have successfully grown. That improvement of the 'exit' proves very conducive to mobilizing early-stage finance (Bottazzi and Rin 2002; Da Rin et al. 2006). Framework conditions relevant to this process include most notably the tax regime. For example, a favorable capital gains tax tied to specific kinds of innovation will allow early-stage investors to reduce their tax burden (Keuschnigg and Nielsen 2003,2006 ). An entrepreneur-friendly bankruptcy legislation would create technology push by encouraging more (or rather deter less) potential entrepreneurs to enter the highly uncertain green tech sector (Cumming 2011; Lerner 2002). If you wish to promote experimentation, you must reduce the penalties on failure. The balance should thus be moved from protecting creditors to protecting those that take the risks that society needs to take on. In a similar vein, flexible labor-market legislation for start-ups will increase their flexibility and chances of survival (Cumming 2011), perhaps at the expense of previously well-protected workers. Flexibility, however, is an important criterion for early-stage investors.

Lerner $(2002,2009,2010)$ provides more specific guidelines that emphasize public venture programs. These should be market-driven and flexible in terms of location, type of securities used and the evolution of firms. A steady hand in policy making is of equal importance, as is reflexivity in assessing program outcomes. This is to assure flexibility as well as ensure 
continuous success based on creativity (Wüstenhagen and Menichetti 2012). Finally, soft policies - such as education and training of market actors, networking, creating clusters of entrepreneurs and syndication opportunities for investors, information diffusion-lower the transaction costs, build trust and could create a more efficient market for matching ventures to investors (Bertoni et al. 2015; Franke et al. 2006; Gompers and Lerner 2001; Nightingale et al. 2009).

In order to effectively shape and create markets that are attractive to early-stage investors such as business angels and venture capitalists, scholars have suggested a combination of both policy approaches in a mix (Mazzucato 2013b, 2016; Rogge and Reichardt 2016). Rather than focusing exclusively on the supply of private finance or the demand from innovative companies, an effective policy mix will combine interventions that increase the supply of funds with policies that increase the demand for new, green products and services. We will argue below that in addition, interventions to improve the matching of investors and entrepreneurs may help make such a policy mix more effective.

\subsection{Research Context and Methods}

In this section, we will briefly present the existing policy framework for green tech innovation in the Netherlands and Sweden and elaborate on methodological choices. Taking two comparable but different countries has the advantage that one can compare the institutional (and policy) context in which decisions are made.

\subsubsection{Policies for Green Tech Innovation and Entrepreneurship in the Netherlands}

The Dutch Government (see, e.g. 'Energierapport 2011' and 'Nationaal Energie Akkoord 2013') aims to balance the desire to promote growth and remain competitive with the transition to a carbon-poor energy system while keeping supply secure. Energy policy is typically approached as an economic policy. The Dutch policies have a strong focus on corporate $\mathrm{R} \& \mathrm{D}$, creating a level playing field, strengthening existing competitive strengths and promoting efficiency.

The Netherlands has adopted the EU energy-efficiency directive, aiming for efficiency improvement of $1.5 \%$ annually between 2014 and 2020. To achieve that aim it levies an energy tax and participates in the EU emission 
trading system. Under the 'Energie Investerings Aftrek (EIA)' there is a tax deduction of energy-efficiency investments by firms. Policies also cover energy-efficient production means under the 'Milieu Investerings Aftrek' (tax deductibility of environmentally friendly investments) and 'Versnelde Afschrijving Milieuinvesteringen' (allowance for faster write-off of environmental investments) programs. In addition to these generic policies, the Government runs some programs that specifically address sustainability issues. Notably, specific programs address the split incentive problem in rented real estate and the lack of information and knowledge in small- and medium-sized businesses. The European Directive on Energy Services is implemented in the 'Energiebesparingswet' (law on energy savings) in the Netherlands. That law details the monitoring standards for energy efficiency, information about energy consumption, energy-efficiency standards and smart metering.

The Dutch Government supports innovation and R\&D in a variety of ways. Around $€ 2$ billion of government funds annually are spent on innovation and $\mathrm{R} \& \mathrm{D}$. These programs are highly relevant, because green tech ventures are typically innovative and $\mathrm{R} \& \mathrm{D}$ intensive. The main program is the 'Wet bevordering speur- en ontwikkelingswerk (WBSO)', a generic program that subsidizes R\&D wage costs (at €700 million in 2013). In addition, the 'Research en Development Aftrek (RDA)' allows firms to deduct expenditures on materials and other costs in R\&D. In 2013 the RDA program was worth $€ 375$ million and applied to about $€ 2$ billion worth of private sector R\&D expenditure. Finally, profits based on new intellectual property are generally treated very favorably in the Dutch tax system. ${ }^{2}$ In more targeted programs, the Government provides guarantees and loans, particularly facilitating innovative SMEs in obtaining bank credit and other funding. Increasingly, the Dutch Government also tries to provide information and business services to innovative and growth-oriented SMEs. It is beyond the scope of this chapter to list and discuss all policies currently in place in that area.

In addition to the R\&D and energy-efficiency efforts, the Dutch Government will spend $€ 2.4$ billion in 2017 (rising to $€ 3.8$ billion in 2020) in the so-called Stimulering Duurzame Energieproductie (SDE) policy. The SDE program is a subsidy scheme that offers a feed-in tariff for renewable electricity production. The program sets a price per technology based on industry averages (base price). Suppliers using that technology are then compensated for the difference between the relevant market energy price and this base price in a competitive bidding procedure. The subsidy is 
limited in time, depending on the technology (e.g. ranging from 5 years for some forms of biomass up to 15 years for solar and wind).

Most Dutch programs aim to improve the net present value and reduce price risks of investments in green projects. Finally, to accommodate and smooth out more volatile renewable (wind) energy production and deal with fluctuating demand for gas and electricity, the Dutch transmission system operator invests in integrating the grid with the northwestern European energy markets and provides guaranteed access to the grid for renewable producers (including offshore wind parks).

In conclusion, Dutch policy makers take a rather straightforward approach to energy policy in the sense that they strongly rely on financial incentives and expect these to get the transition going. As a consequence, to date there is little targeted investment in promising, yet unproven, technologies - and policies aim to reach rather modest targets with minimal means.

\subsubsection{Policies for Green Tech Innovation and Entrepreneurship in Sweden}

Sweden also adopted the goal of no net emissions of greenhouse gases to the atmosphere by 2050 . Sweden's policies include measures to improve excellence in research but also stimulate the commercialization and the development of new technologies. To address climate change, Sweden has implemented the highest carbon tax in Europe for all sectors not covered by the EU emission trading scheme. In addition, an energy tax is levied on electric power and fossil fuels to induce energy efficiency. Renewable fuels are exempted from energy and carbon taxation, though EU regulation does not permit Sweden (or any other member state) to overcompensate renewable fuels, meaning that the main biofuels (biodiesel and ethanol) are now taxed, albeit at a lower level than their fossil equivalents. Compliance with tight environmental standards entitles the user to a tax exemption for new passenger cars, and buyers of the most efficient cars get a bonus of $€ 4000$. To support renewable energy production, Sweden has introduced a renewable energy certificate (REC) for each MWh produced. Electric power distributers are forced to buy RECs up to a certain proportion of the power distributed. Swedish tax law also allows wind power investments to be depreciated at an accelerated rate.

The National Environmental Technology Strategy had a total budget of $€ 48$ million during the period 2011-2014. With this money, the Swedish Government supported firms to meet sustainability challenges while 
promoting new business and employment. The program comprises a broad range of short- and long-term initiatives and targets innovation and exports. At the end of 2013 Sweden introduced tax benefits for private investors investing in unlisted companies.

Public-owned incubators, such as Almi and Innovationsbron, play a big role in enabling growth of small- and medium-sized enterprises in Sweden. To increase the supply of private capital for early-stage companies, Sweden has also set up a public fund to invest in new and current private VC funds. Public VCs 'Fouriertransform AB' and 'Inlandsinnovation AB' are examples of Sweden's efforts to increase the flow of private capital to (green tech) innovations.

The Swedish Energy Agency aims to facilitate the connection of actors in green tech and thus increase cooperation between them. Finally, Swedish innovation agency VINNOVA has allocated funding to bridge the 'valley of death', that is, the perceived gap between public-financed research and privately financed diffusion processes. Their activities include method development, standardizing, certification and the development of infrastructure for innovative efforts and/or firms.

In conclusion, Swedish policy making is much more decentralized in its governance; not in a regional sense, but institutions are more independent and more government agencies take responsibility for a wider range of programs. Less is spent on subsidies and more effort is put into developing networks and exchanging knowledge.

\subsubsection{Policy Summary}

There are policies targeting innovative SMEs in both countries, whereas policies targeting investors are less common. In Sweden, policies aim to increase the inflow of venture capital and increase awareness through the supply of information. In the Netherlands, initiatives aim at increasing the supply of information but also include fiscal and financial incentives such as tax breaks and specifically for green tech, feed-in tariffs.

Energy policies are governed very differently in the two countries. In the Netherlands, it is usually 'AgentschapNL', an agency of the Ministry of Economic Affairs, that implements and manages the policies. In Sweden, by contrast, different agencies in different ministries implement a more varied range of policies. The governance of the policy instruments has a clear impact on the way the policies are set up and implemented. In the Netherlands the focus on cost-effectiveness and fair competition is perhaps 
stronger, whereas in Sweden more attention is paid to networking and information provision. The underlying assumptions on human and more specifically entrepreneurial and investor behavior differ somewhat.

The policies to promote the supply of venture capital and entrepreneurship in the green tech sector are directed toward the provision of information to overcome information asymmetries in Sweden. Policies in the Netherlands use more traditional economic policy instruments, improving the return on ventures and investments themselves and relying on rational private agents to then respond to financial incentives.

\subsubsection{Data Collection and Analysis}

To shed light on the effectiveness of public policy initiatives for mobilizing private early-stage investments, this research combines an archival document analysis (Adenfelt et al. 2013) with a series of 30 in-depth interviews (Adenfelt et al. 2014) and a structured online survey of 74 Dutch and Swedish investors and entrepreneurs (Polzin et al. 2017b). In the survey we implemented a few open questions eliciting respondents' views on appropriate policies to promote early-stage investment in (green tech) ventures. We therefore collected and evaluated entrepreneurs' and investors' views on policies targeting early-stage green tech investments using three different data collection methods. Desk research, interviews and survey methods were combined as they complement each other and result in a more comprehensive understanding of the phenomena studied (Creswell and Clark 2010; Jick 1979). Both sets of study subjects (investors and entrepreneurs) represented typical cases (Seawright and Gerring 2008). The combination of three data sources and mixed research methods allows for triangulation (Moran-Ellis et al. 2006).

We asked broad open questions, leaving as much room as possible for the interviewees and survey respondents to express their views (Patton 2002). In the interviews people were asked about general characteristics of the firm or investment fund and their role in that organization. Other questions revolved around the funding process from an investor's perspective and the firm foundation process from an entrepreneur's perspective. Finally, we asked both investors and entrepreneurs in the interviews and the survey about the policy environment and their preferred political intervention in the Netherlands and Sweden. 
Table 13.2 Investors' and entrepreneurs' perspective on policies to mobilize earlystage finance

\begin{tabular}{|c|c|c|c|}
\hline Category & Policy measure & $\begin{array}{l}\text { Effectiveness } \\
\text { (investors) }\end{array}$ & $\begin{array}{l}\text { Effectiveness } \\
\text { (entrepreneurs) }\end{array}$ \\
\hline \multirow{2}{*}{$\begin{array}{l}\text { Fiscal and financial incen- } \\
\text { tives (R\&D support) }\end{array}$} & $\mathrm{R} \& \mathrm{D}$ subsidies & + & \\
\hline & R\&D tax credits & + & + \\
\hline $\begin{array}{l}\text { Systemic instruments } \\
\text { (R\&D support) }\end{array}$ & $\begin{array}{l}\text { Research infrastructure and } \\
\text { incubators }\end{array}$ & ++ & + \\
\hline Market-based incentives & $\begin{array}{l}\text { GHG emission trading } \\
\text { system }\end{array}$ & & \\
\hline \multirow{6}{*}{$\begin{array}{l}\text { Fiscal and financial } \\
\text { incentives }\end{array}$} & Cash rebates and subsidies & - & $+/-$ \\
\hline & $\begin{array}{l}\text { Direct investments (into } \\
\text { complementary assets) }\end{array}$ & $+/-$ & \\
\hline & $\begin{array}{l}\text { Co-investing (into } \\
\text { companies) }\end{array}$ & ++ & $++/-$ \\
\hline & Loans and loan guarantees & ++ & + \\
\hline & Tax incentives & ++ & ++ \\
\hline & Feed-in tariffs & $+/-$ & + \\
\hline Regulatory measures & $\begin{array}{l}\text { Product standards and } \\
\text { regulation }\end{array}$ & -- & \\
\hline \multirow[t]{2}{*}{ Systemic instruments } & $\begin{array}{l}\text { Information, networking } \\
\text { and conferences }\end{array}$ & + & \\
\hline & Public procurement & + & + \\
\hline \multirow[t]{6}{*}{ Framework conditions } & $\begin{array}{l}\text { Capital market development } \\
\text { (exit possibilities) }\end{array}$ & + & \\
\hline & Tax policy & + & \\
\hline & Bankruptcy legislation & & \\
\hline & Labor-market regulation & + & + \\
\hline & Intellectual property & & + \\
\hline & Institutional investors & + & \\
\hline
\end{tabular}

Some interviewees highlighted the measure as positive $(+)$ or negative $(-)$; many of the interviewees highlighted the measure as positive $(++)$ or negative $(--)$

\subsection{Findings And Discussion}

Having established the research context and discussed the policy landscape in both countries, this section presents the entrepreneurs' and investors' perspective on policy measures to mobilize private finance for green tech ventures based on the interviews and the survey. Hence we firstly elaborate on specific views about green tech investments in Sect. 13.4.1. Section 13.4.2 presents and discusses the policy perspective of entrepreneurs. Then we turn to the investors in Sect. 13.4.3. A summary and comparison of the findings can be drawn from Table 13.2. 


\subsubsection{Entrepreneurs' and Investors' View on Green Tech Investments}

Entrepreneurs do not perceive the green tech market as being efficient or even rational. The investors are described as being guided by feelings and behavioral heuristics when making the investment decision.

If you look at angels, i.e. small private investors, they invest to a great deal, how to say this, with the heart and with regards to knowing people. (Swedish Entrepreneur)

Entrepreneurs also assert herding behavior to investors and portray them as running in parallel or as following a lead investor.

2007 Al Gore was in the news and all this. Everything was green tech. And there were all these investors that I know and it was like - high-five - and everyone had switched over to be green tech investors. (Swedish Entrepreneur)

On the other hand, some investors view green tech entrepreneurs as highly technically skilled but lacking business and finance skills, even more so than entrepreneurs in other sectors.

Green tech entrepreneurs are different. Less degree of professionalism and more Gyro Gearloose. (Swedish Investor)

This observation is consistent with the view held by investors and entrepreneur alike that Swedish green tech investments are still being suppressed by a previous market bust. Many respondents expressed that the early green tech hype lacked foundation in reality and when the bubble burst, many investors shied away from the market and still are.

Green tech jumped up a few years ago and was very hot. Then the people that invested got burned but this has been coming and going. So you have felt a bit of a head wind but also a gigantic interest. (Swedish Investor)

The Dutch green tech market did not experience the same boom and bust as the Swedish, and consequently the importance of market track records is not as articulated in the Dutch responses.

The actual match on the market, the fit between the wishes of the venture capital firm and the green tech model seem to be a major concern on both sides of the market (see also Bertoni et al. 2015; Franke et al. 2006; 
Polzin et al. 2017b). The closed-end funds, the stringent mandates, the large investments and the required returns are fundamental constraints for closing the deal with green tech firms that often has large capital requirements and long-term horizons as well as substantial risk.

This type of rigorous behaviour I often see with investors. They follow their rules and are in general not very flexible. [...] The impact globally is huge, but rules seem more important. (Dutch Entrepreneur)

Difficult to make money in this equity gap if you are a closed end fund. There is not enough time to build a company. [...] Green tech is difficult. Since the time horizon is long most business models do not fit. (Swedish Investor)

A large concern of investors is the prevalence of policy failure and policy risk which many investors have experienced as a major obstacle for investing in green tech. Thus elaborating on their perceptions about the policy environment is pivotal to inform policy makers and other stakeholders.

\subsubsection{Entrepreneurs' View on Public Policy to Mobilize Green Tech Investments}

\subsubsection{RéD Support}

Generic or specific R\&D support to address the largest uncertainties in the innovation cycle relieves early-stage financial pressures, the so-called valley of death, for highly innovative start-ups. Such innovation life cycle policies, however, are mentioned less frequently than the more traditional financial measures. Still, entrepreneurs seem aware that the financial implications of supporting R\&D could be significant.

There is a policy that reduces tax for people that are doing RoD [...] If that policy changes and we have to pay more taxes, that will be another 2000 euros per month. (Dutch Entrepreneur)

Conventional economic wisdom points out the usefulness of continuous and directed R\&D support for the general advancement of green technologies and other high-impact innovation on the knowledge markets. However, such support only plays a subordinate role when referring to earlystage investments (Acemoglu et al. 2012; Olmos et al. 2012; Veugelers 2012). The research infrastructure and the possibility to generate 
intellectual property seem more important for green tech venturing (Kenney and Hargadon 2012, 2014). Apparently, the obvious policies, stronger intellectual property protection, tax reductions and subsidies for R\&D are typically not top of mind for the entrepreneurs. The interviews also show that entrepreneurs evaluate such policies mostly from a rather narrow micro perspective. That is, they do not consider more radical reforms or policies, such as open-source innovation or publicly funded basic R\&D, where impacts are likely to result at the macro level (Jaffe and Lerner 2011). On the one hand, we can conclude that a policy focused exclusively on the opinion of entrepreneurs will typically miss important elements of an effective transition policy package. On the other hand, the overall positive views do suggest that generic and specific support for green tech basic R\&D and a strong knowledge infrastructure are useful.

\subsubsection{Fiscal and Financial Incentives}

Financial incentives are the type of policy most frequently mentioned by entrepreneurs in the survey and interviews. However, the views on existing policies are not entirely positive. Policy design was sometimes seen as misdirected or insufficient. Subsidies for technologies or firms are clearly perceived as effective in the sense of being a direct positive effect on profitability, but not always as fair and efficient.

So if you enter a market with a new solution and you have to compete with solutions that have been subsidized, then you cannot compete. Why are these subsidies there and what is being subsidized? (Dutch Entrepreneur)

The issues of unfair competition and uncertain long-term commitment make subsidies unpopular. Notwithstanding, few entrepreneurs mention more stable support systems, such as a feed-in tariff, where the government guarantees a certain price for electricity produced from renewable energy sources, or a market for electricity certificates, where producers receive tradable certificates for each KWh renewable electricity produced. Here, too, the design and distribution of benefits is decisive for entrepreneurs to build their business model on such a mechanism.

These polices need to be understood... for instance, if you do want some polices, let's say feed-in tariffs, then it depends on who it benefits. Does it benefit the people that invested their capital initially? [...] This needs to be well understood as a system. (Dutch Entrepreneur) 
This quote shows that entrepreneurs do reflect upon the implications of policies for their investors. In addition, directed tax incentives (for investors) targeting companies with a sustainable product, service or business model may also be beneficial for attracting early-stage investments. Many entrepreneurs mention these instruments spontaneously. But here also, the design and bureaucracy involved in proving eligibility for these tax breaks were mentioned as issues that significantly reduce their effectiveness.

If you want to support us as a company you could do one of those investor grants but [...] it was like a whole week of work and difficulties with getting your head around if you could use it or not. And this limits the value to us. If you had made it a bit more liberal - so, for example, it could be applied to institutional investors - it would have helped us for fundraising. (Swedish Entrepreneur)

When asked about policies they would propose, entrepreneurs most frequently suggest that the government could do more in terms of increasing the flow of (public) funds to early-stage venturing in the green tech sector. On the one hand, government officials sometimes see private sector co-investing as critical due to vested interests and missing competencies. On the other hand, entrepreneurs argue that some companies should be 'earmarked' for impact investments as a form of mission-driven governmental co-investment. But typically, such argumentations are to some extent self-interested.

As an alternative to equity investments, a few entrepreneurs mention governmental loans or revenue stakes.

Somebody must take this risk and EU/the government has the possibility to support early-stage investments via VCs. (Swedish Entrepreneur)

Beyond the direct (impact) investments by governmental agencies, entrepreneurs do not see or appreciate the need to combine government funds with private co-financing. To entrepreneurs, this restriction seems a useless complication, whereas for policy makers it is a way to justify and be accountable for the choices being made.

Well, there is almost only one thing and it is to remove the demand of co-financing from the government funds. (Swedish Entrepreneur) 
These results in general fit the discussion about the usefulness of subsidies for green technologies. Entrepreneurs are split over these questions (Bürer and Wüstenhagen 2009). Design and stability of support systems to build a business model are important from an entrepreneur's point of view (Criscuolo and Menon 2015; Haley and Schuler 2011). Regarding tax incentives, instead of focusing directly on the firm-for example, through a production tax credit (Barradale 2010)-entrepreneurs interestingly mention tax breaks for investors as one key element of attracting private finance. The importance of governmental co-financing and risk taking of innovative green tech firms is emphasized by many entrepreneurs, although caveats regarding bureaucratic requirements and increased complexity in the relationship between public and private investors are raised (Olmos et al. 2012). Finally, it is interesting to note that none of the entrepreneurs spontaneously mentioned the type of broad economic policy measures, such as carbon taxes or emission trading systems, which economists tend to recommend as the preferred policy instrument. We may conclude from our data that entrepreneurs will typically mention the obvious policies and policy instruments. Governmental co-investing and tax breaks are what entrepreneurs first think about when policy questions are raised. Our results also suggest the entrepreneurs are keenly aware that the design of such policies matters a great deal and may in fact result in blocking, rather than promoting green entrepreneurship. It is also clear that entrepreneurs (like investors below) will evaluate policies exclusively from their perspective. An important lesson for policy makers is that optimal policies in the eyes of entrepreneurs, even very successful ones, do not necessarily represent the societal optimum. Sometimes it remains opaque how the selection for co-investments occur and this sits uncomfortably with the requirements of democratic accountability and legitimization.

\subsubsection{Regulatory Instruments}

Market regulations such as industry standards or renewable portfolio standards to promote capital and product markets were only mentioned by one of the participating entrepreneurs. This illustrates that more direct interventions such as financial and fiscal incentives are more visible yet not more important than functioning markets. The role of environmental standards and regulation as a source of new competitive advantage has been proposed by Michael Porter (Porter 1991; Porter and van der Linde 1995). More recent empirical work also highlighted their perceived usefulness for 
investors (Bürer and Wüstenhagen 2009). It is interesting to note that the entrepreneurs in our sample do not see a role for regulation and standards to promote their business. At least, they do not mention them spontaneously.

\title{
13.4.2.4 Systemic Instruments
}

Besides the main determinants of functioning markets for green tech innovation, only a few entrepreneurs mention policies aimed at diffusing information and creating networks, such as incubators, fairs or platforms.

\begin{abstract}
Do a lot more things like they do in Delft or Amsterdam, providing locations, stimulating get-togethers, stimulating platforms for people to become vocal and where they can express themselves, ensuring media pays a lot of attention to it. (Dutch Entrepreneur)
\end{abstract}

They recognize what incubators aim to do but also feel their usefulness is yet to be proven.

Incubators can provide entrepreneurs with the right tools and right education to make the ideas ready and provide a higher hit rate for investors, making them more willing to invest their capital. (Swedish Entrepreneur)

Rather than creating networks with private equity investors, some entrepreneurs propose initiatives to match start-ups with large corporations to open up for corporate innovation.

I would propose an early match with an existing firm or organization which is in need of a service that match the start up. The start-up can adapt too specific requirements and then have the flexibility to scale up the production. (Swedish Entrepreneur)

The positive view on establishing channels for contact between entrepreneurs and investors (Bertoni et al. 2015; Gompers and Lerner 2001) is not broadly shared by the entrepreneurs in our sample. They do see that the incubators and fairs can be useful but do not seem to consider the flow of information and building of networks to be very conducive to green tech business development. Entrepreneurs perhaps underestimate the importance of building social networks and establishing relationships (Polzin et al. 2017b). Policies that promote such network building are not top of their minds but perhaps serve a more important function than they would 
recognize. It seems only logical that entrepreneurs would attribute success in attracting investors and customers more to the quality of their product and team than to the quality of the network in which they find their matches (Franke et al. 2006; Ruef et al. 2003).

\subsubsection{Framework Conditions}

Apart from measures specifically targeting the green tech sector, entrepreneurs highlight general framework conditions for entrepreneurship as important for their activities. Such framework conditions include legal issues and bureaucracy relating to the start-up process, as well as labor-market regulations for small firms. Both interviewees and survey participants agree that policies should focus on the start-up process itself, regardless of the sector. In that respect, entrepreneurs naturally complain about bureaucratic 'red tape'.

Governmental support is quite good in Sweden, but lower taxes, fewer regulations, less influence by unions for these companies would help. Less money would be needed and more companies could grow with the money already available. (Swedish Entrepreneur)

Especially labor and wage regulation including tax laws often is perceived to hinder start-ups and innovative firms.

Remove the required minimum salary for directors for start-ups (e.g. below a certain amount of revenue or time in business). (Dutch Entrepreneur)

For Sweden, adopt the British SEIS regulations, and stop the so called 3:12 tax regulations [dividends up to a threshold amount taxed as capital, while dividends above that amount is taxed as earned income]. (Swedish Entrepreneur)

In addition, a few entrepreneurs mention specifically the importance of intellectual property rights and how the government can support this process.

I know that they have had something like this in the US, where the government or the local authorities have financed the development of intellectual property and I think this is important. (Swedish Entrepreneur) 
The view of the interviewed entrepreneurs is very much in line with what Lerner and colleagues state about designing effective venture capital support programs (Lerner 2002, 2009, 2010). They call for an understanding of the details of the early-stage investment process (including its legal and institutional environment) in order to effectively engage private investors. More specifically this implies in the contexts of Sweden and the Netherlands that labor regulation and protection should be simplified and perhaps reduced for small and young firms. Such reforms would not only increase flexibility and reduce the risk of illiquidity and bankruptcy but also increase the pool of talent that entrepreneurs could draw on (Cumming 2011; Lerner and Tåg 2013). The lower tax and social security burdens that such reforms would imply could increase the profitability and potential for self-financed growth of young firms. Again, the entrepreneurs very much take their own perspective and do not consider the impacts this may have on the labor market at large and the position of workers in the economy.

Taking together all the results, on the one hand, entrepreneurs tend to take a micro perspective on policy making. This leads them to push for governmental co-investment and risk taking, stronger intellectual property protection, less restrictive labor-market regulations and $R \& D$ tax breaks for start-ups. On the other hand, they neglect the importance of finding a matching investor through structured initiatives like incubators or conferences. Hence, to develop an effective policy mix we also need to consider the perspective of investors and combine that into a policy mix that serves the interest of society (through the diffusion of green technologies), not specific stakeholder groups.

\subsubsection{Investors' View on Public Policy to Mobilize Green Tech Investments}

\subsubsection{RóD Support}

Generic R\&D support not interfering with the commercialization process and scale-up of start-ups is generally seen as a positive measure by investors. It reduces technological uncertainty and risk across the board, if information is shared and available.

ReD support that facilitates clustering etc. has a big effect when it comes to capital/VC. (Swedish Investor) 
It also relieves innovative start-ups and their investors of financial constraints relating to $R \& D$ expenses.

In fact, two of our portfolio companies - one in the UK and one here in the Netherlands - are getting a decent chunk of their R\&D money back, which is great. (Dutch Investor)

Investors generally perceive $R \& D$ support as helpful since it does not intervene in the phase where early-stage investors engage (Acemoglu et al. 2012; Olmos et al. 2012; Veugelers 2012). It is, however, typically considered a 'nice to have' and helpful environmental factor that is not deemed crucial in promoting private investment in green tech start-ups. Investors do not seem to consider the general lack of technical knowledge a major barrier to investments. This might be the result of them operating in highly developed and high-tech economies like Sweden and the Netherlands. They may take for granted the general high levels of public and private R\&D (Mazzucato 2013a).

\subsubsection{Fiscal and Financial Incentives}

Investors also mainly mention financial incentives and economic instruments in response to an open question on preferred policies to promote green tech investments.

Clean energy subsidies, or guarantees or feed-ins or anything like that, matters a lot. (Dutch Investor)

However, as the entrepreneurs, investors do not consider all instruments to be useful. Some investors are even outright negative about subsidies, because they destroy or misalign the incentives for entrepreneurs.

But you see now with subsidies, in fact subsidies are a bad system. Because it's free money. And you know that subsidies are misused - almost by definition. (Dutch Investor)

Moreover, even in countries with reliable governments such as Sweden and the Netherlands, investors consider business models that rely heavily on subsidies an undesirable risk. 
This is such a large risk so if there exist one, we are not getting involved. It is important that subsidies and the subsidy system is constructed such that the subsidy levels are secured from day one. (Swedish Investor)

More comprehensive support schemes, such as feed-in tariffs, could be seen as positive, especially for less mature and more risky technologies, if the commitment of the government is credible.

We look at the stability of the feed-in tariffs, this is really important concerning tidal energy projects. Tidal energy is really in its early stages and you look if there is a certain feed-in tariff we have to know for how many years to take the risks into account. (Dutch Investor)

Whereas many investors propose access to risky loans, loan guarantees are also evaluated differently, depending on the conditions the government sets.

Many investors, especially business angels but also governmental VCs, also emphasize directed tax incentives, such as investor tax credits, to stimulate green tech industry emergence.

Of course, the terms of our co-investors and their ability to make tax deductions on their investments. For us that is a very important issue. [...] What can they do? How complicated is it for them? (Swedish Investor)

A few investors even suggested that, [t] here should be special tax incentives for social impact investments (Swedish Investor).

Many investors, and business angels in particular, highlighted governmental co-financing or promoting policies for co-investors, as a way of improving green tech investments. Such co-financing was mentioned as a way to leverage the available private capital.

Yes, for instance if we as angel investor could co-finance together with the government, that the government can match our investment, that is one of those things. (Swedish Investor)

Regional investment funds could be helpful if there is matching private capital. (Dutch Investor)

Overall, investors point out slightly different aspects in the design as entrepreneurs. For example, investors refer to the design of the subsidy 
scheme in terms of predictability as decision determinant, whereas entrepreneurs care more about equal access and fair competition. These findings seem to confirm the usefulness of comprehensible fiscal and financial incentives for mobilizing private early-stage investments, especially for infant technologies (Bürer and Wüstenhagen 2009; Criscuolo and Menon 2015; Haley and Schuler 2011). Loan guarantees could allow new and small companies to scale up. However, these should first and foremost fit the capital needs of the entrepreneur (Kenney and Hargadon 2012, 2014). But there are also investors that avoid subsidy driven business models or companies indicating too much policy risk. In the Netherlands and Sweden such considerations play a major role. They will therefore be even more relevant in countries with less stable fiscal and public policies and political systems.

Interestingly, co-investment with public partners is positively evaluated even though investors then must deal with a public shareholder. This contradicts earlier findings (Migendt et al. 2017). Investors, in contrast to entrepreneurs, like the government to co-invest. But they do not want their investments to be dependent on long-term government support. This probably goes back to the fact that in co-investment, the government is automatically committed up front and political commitment beyond the investment decision is not required. It is much easier to cancel a subsidy scheme than it is to reclaim investments once they have been made. This lends support to the idea that mission-driven public investments by state investment banks to accelerate green innovation could work (Mazzucato and Penna 2016). Lastly, it could be noted that just like the entrepreneurs the investors do not spontaneously mention the broad type of economic policy measures, such as carbon taxes or emission trading systems, recommended by economists.

We conclude from the interviews and survey of investors that government financial interventions need to be first and foremost credible to be effective. And investors do not trust the government to honor long-term commitments without some sort of credible commitment device. Direct co-investment, grants and tax credits work. Subsidies and fickle feed-in tariffs are much less effective as their credibility is more in doubt.

\subsubsection{Regulatory Instruments}

The importance of stability and long-term commitment is also apparent in the interviews when it comes to regulation. Consistent market rules reduce risks and create predictability and stability in the market. The policy risk is 
still considered the most prominent risk and hardest to manage in the green tech business.

Sectors that are heavy regulated [...] are also very difficult to invest in. We cannot handle policy risk. We do not understand it and we will never lobby in Brussels. (Swedish Investor)

Hence investors shy away from artificially created markets and complexly regulated environments.

Regulation does create markets, but like artificial market creation, so for us, although it is generally not true for a lot of investment platforms, we do not make our decisions based on that, naturally we shy away from areas where the markets bave been artificially supported, and because that creates bubbles, and you know, as soon as that sparks it collapses those markets. (Dutch Investor)

Regulations that create a level playing field between fossil-fuel-based companies and green firms are less easily retracted, and hence investors prefer them over policies that support renewables (Bürer and Wüstenhagen 2009; Polzin et al. 2015). Market creation for green tech through these measures is perceived as critical by academics (Mazzucato 2016). The message we take home from our interviews and surveys, however, is a different one. Investors stress, in many ways, the need for a stable business environment. They cannot manage and do not want to engage policy risk. The underlying intuition of the 'Porter hypothesis' (Porter and van der Linde 1995) is being rejected by the investors in the sense that not strict but rather long-term stable policies can fulfill the role of creating new competitive advantages for firms.

\subsubsection{Systemic Instruments}

Beyond fiscal and financial support and regulation of markets, investors see incubators, diffusion of information such as market intelligence and education for early-stage investors, as positive and encouraging for their investments. They feel the government could take a more active role in promoting such events and activities.

We usually like companies that come out of incubators. (Swedish Investor) 
Educate private investors in professional angel investing, train for better due diligence, make it easy to organize syndicates of investors, and help investors get cashflow while still continuing to invest in early stages. Lack of liquidity is a big problem, and so lack of diversified portfolios. [Business angels are] undercapitalized, underprofessionalized and underorganized. (Swedish investor)

Some investors favor direct government involvement in the form of systemic and mission-oriented procurement to stimulate initial demand for green tech products and services to decrease costs. Being a launching customer is also a commitment that need not be long term and typically does not span multiple election cycles. A more activist, innovation-oriented procurement policy is certainly appreciated by investors.

Government, municipality and regional public agencies can go in and say: ' $\Upsilon_{e s,}$ we would like to do a procurement but a share of it must be for these smaller firms'. (Swedish Investor)

Our analysis shows that soft measures such as the creation of incubators are also deemed sensible (Bertoni et al. 2015; Gompers and Lerner 2001). Direct government involvement in the form of public procurement and indirect government involvement through long-term planning and developing networks and information exchange in incubators reduces investor risk and hence mobilizes private finance (Edquist and Zabala-Iturriagagoitia 2012; Wüstenhagen and Menichetti 2012). It is interesting to note, however, that investors typically evaluate such policies more important than entrepreneurs. Moreover, they even consider these policies more important than entrepreneurs think they do. That is, there seems to be a mismatch in the perception on this point (see also Polzin et al. 2017b).

\subsubsection{Framework Conditions}

Beyond supporting green tech markets, a functioning equity market to successfully exit their investments is a prerequisite for mobilizing more early-stage investments. Hence, to complement initiatives directly aimed at the green tech sector, framework conditions for $\mathrm{VC} / \mathrm{PE}$ matter as well. Here, most investors see barriers for their engagement.

For venture capital in Europe [...] there are a lot of great companies, a lot of great deals, but for the companies to become really large and for good exit opportunities, more money needs to be around. We see a lot of great companies, 
we cannot invest in all of them. At the moment, it is great for us, we get to be really picky about our deals. (Dutch Investor)

More specifically, a few investors also stress the importance of legal protection of the product. They care about the imitability of the technology and see intellectual property as an effective way to secure returns.

Intellectual property becomes increasingly important (to us and others). The best idea in the world is not worth so much if you do not (or cannot) lock it in with an appropriate intellectual property portfolio. (Swedish Investor)

As the entrepreneurs, investors clearly evaluate this issue from the current situation. Intellectual property is considered valuable because it increases the profitability of firms that have patented their technology. The fact that patent protection may inhibit diffusion and imitation is considered a good thing from the perspective of the investor. On a societal level, however, stricter patent protection may also lead to less competition and innovation.

Some investors further state that pension funds should be given more possibilities to allocate private capital into green tech. Their mandate and new regulation requires them to reduce risks. That is, move out of venture capital and even out of the general stock market (important as an exit channel for VCs to sell their shares) and invest their funds into more secure and liquid government assets.

I would use my power to force Dutch pension funds to make their money available to Dutch industry and Dutch society. (Dutch Investor)

Pension funds and institutional investors [should also] decide to allocate a larger part of their capital to a green tech fund. (Dutch Investor)

With over 1000 billion in assets under management (Tan 2016), pension funds are looked at by investors, especially in the Netherlands. The micro perspective the investors take, however, makes them rather insensitive to the fact that these pension funds have investment policies that preclude high-risk $\mathrm{VC}$, also in green tech investments, to protect pension fund beneficiaries from losses. On the other hand, unleashing (a share of) these resources for investments in the sustainability transition is societally beneficial.

Finally, investors also highlight high taxes on firm profits, payroll or incentives systems as decreasing private investment in green tech venturing. 
Labor-market regulation is mentioned as a deterrent for green tech entrepreneurship as flexibility is a key factor in the early stages of the company life cycle.

It is more on a macro level, making it easier to hire people. Then you can build a team and repay them with stocks. (Swedish Investor)

Also the investors highlight very clearly the general framework conditions for early-stage investments as critical barriers to stronger engagement in green tech (Bottazzi and Rin 2002). Especially, tax legislation and labormarket rules need to be reformed (Keuschnigg and Nielsen 2003, 2006; Lerner and Tåg 2013).

To summarize from the interviews and survey, most importantly, many investors mention long-term policy commitment as vital for investing in the green tech sector.

The most important thing is probably that you get some (policies) that are stable over time. [...] So that they become calculable.[...] There is too much instability around these policies. (Swedish Investor)

Just clarity on the long term [...] the biggest problem that we have is that it changes every year. (Dutch Investor)

Technologies, products and business models are still highly dependent on the policy environment. Major renewable technologies may have reached grid parity (e.g. the levelized costs of energy from renewables are as low as from fossil fuel sources), but policies can still significantly affect their respective business cases. The lack of predictability looms large in the minds of investors in Sweden and the Netherlands alike.

\subsection{CONCLUSIONS}

Early-stage equity capital is a small but essential component of a healthy financial ecosystem (Fricke 2016; Migendt et al. 2017; Perez 2013). A diverse financial system consisting of a multitude of actors that cover a variety of risk/return profiles and therefore finance different companies' projects and infrastructure is firstly more stable and thus more resilient to shocks-a core attribute of a sustainable financial system. Secondly it allows for innovation in green tech sectors to be financed which contributes 
directly to a sustainability transition in the real economy-a central of a sustainable financial system (Bürer and Wüstenhagen 2009; Migendt et al. 2017; Polzin et al. 2017a; Wüstenhagen and Menichetti 2012). For these macro-level benefits to materialize, however, governments should try to mobilize more private funding for early-stage green tech investment.

When approaching the problem of lacking private investment in the commercialization stages of green tech products and services, an effective policy strategy should consider the most affected stakeholders (Georgallis and Durand 2017). In this chapter, we therefore interviewed and surveyed them directly to elicit their views and ideas on effective policy interventions. When comparing investor and entrepreneur suggested policies, one needs to relate the responses to the problems as perceived by the market actors in green tech markets. These inefficiencies create a role for governments. However, investors and entrepreneurs diverge on what they regard as problematic and do not necessarily agree on what they consider effective policy interventions. Entrepreneurs more often argue that green tech and impact investment in general warrant special policy treatment, whereas investors consider green tech investments to be no different to any other investment.

Both stress the need for more basic $\mathrm{R} \& \mathrm{D}$ and research infrastructure which often is seen as a 'no-regret' strategy for policy makers. However, it is expected to have little impact on entrepreneurs' and investors' decisions to engage in the green tech sector. Fiscal and financial incentives-in particular, government co-investing and risk taking-are advocated by both parties. Both also assessed the efficiency of such interventions to depend on the stringency, predictability and time horizon of the policy program. Increased governmental market participation could possibly improve the efficiency of the market by internalizing some of the mismatch as investors and entrepreneurs see it. Interestingly, not only investors but also entrepreneurs argue for investor tax credits to accelerate investments. Subsidies and other direct support systems are appreciated by entrepreneurs in so far as it gives positive short-term effects on profitability but is never mentioned an important driver of investments. Investors, on the other hand, express strong aversion toward this kind of support systems and regulation that can easily be rolled back. As a general rule, investors emphasize long-term commitment and a steady hand in environmental and energy policy. Systemic instruments such as public procurement are effective policy instruments mentioned by both entrepreneurs and investors. Soft policy measures, such as networking initiatives, education or information 
diffusion, are not top of mind for entrepreneurs but are evaluated more positively by investors. Opinions differ also on the role of incubators and networking. Interventions to improve the matching between investors and entrepreneurs could be relatively low cost options to increase matching efficiency in the market for venture capital (Polzin et al. 2017b).

Framework conditions for early-stage investments are a clear barrier to early-stage green tech investments, highlighted by both investors and entrepreneurs. Especially, intellectual property legislation, labor-market rules and tax policy are critical barriers to more investor engagement. Both stakeholder groups share the opinion that constraints and taxes should be reduced and intellectual property plays a key role in promoting green tech innovation. Increasing labor-market flexibility is also deemed important by both entrepreneurs and investors.

Our findings suggest that a suitable public policy mix anchored in the stated preferences of both investors and entrepreneurs consists of two components. First demand generating policies, such as tax breaks for green tech entrepreneurs and government seed funding, should be combined with systemic instruments such as incubators for green tech entrepreneurs and public procurement for green technologies. Second, long-term general support for early-stage finance should be given, for example, by adjusting the mandate of pension funds to invest some of their vast resources in risky venture capital, by adapting intellectual property law to allow for more innovation and by reforming labor-market rules to increase the flow of labor to start-ups.

One should not make the mistake of taking survey and interview responses of stakeholders at face value. Well-designed policies also consider the interest of other stakeholders and society at large. But as we have argued, the mobilization of more private capital for green tech innovation has many advantages beyond the benefits that accrue to those directly involved. For one, a more diverse financial sector that channels more resources in the form of equity investments in a socially desirable and ecologically urgent transition of the energy system will arguably be more resilient and sustainable (Polzin et al. 2017a). By shifting the burden of financing the transition, budget constrained governments can stabilize financial markets, boost private economic activity and foster innovation and growth. Our results suggest that the most directly affected stakeholders are ready to act and will not object to well-designed policy interventions to promote that transition. 


\section{Notes}

1. Creative destruction (or discontinuities) refers to process by which novel combinations of inputs lead to product, process or organizational innovation that radically change industries.

2. Up to the point that other countries have accused the Netherlands of being a tax haven and allowing large corporates to channel their profits through the Netherlands largely untaxed.

\section{REFERENCES}

Acemoglu, D., Aghion, P., Bursztyn, L., \& Hemous, D. (2012). The environment and directed technical change. American Economic Review, 102(1), 131-166. https://doi.org/10.1257/aer.102.1.131

Adenfelt, M., Sanders, M., \& Stavlöt, U. (2013). Mobilising private funds for the transition to a sustainable economy. Brussels: European Liberal Forum. Retrieved from http://fores.se/wp-content/uploads/2014/05/ELF_2013_final.pdf

Adenfelt, M., Sanders, M., \& Stavlöt, U. (2014). Digging for gold in the green economy: Private investment in green venturing. Brussels: European Liberal Forum. Retrieved from http://www.liberalforum.eu/en/publications.html?file=tl_files\% 2Fuserdata\%2Fdownloads\%2Fpublications\%2F2014\%2FDigging_gold_green_ economy.pdf

Barradale, M. J. (2010). Impact of public policy uncertainty on renewable energy investment: Wind power and the production tax credit. Energy Policy, 38(12), 7698-7709. https://doi.org/10.1016/j.enpol.2010.08.021

Bertoni, F., D'Adda, D., \& Grilli, L. (2015). Cherry-picking or frog-kissing? A theoretical analysis of how investors select entrepreneurial ventures in thin venture capital markets. Small Business Economics, 46(3), 391-405. https://doi. org/10.1007/s11187-015-9690-9

Block, J., \& Sandner, P. (2009). What is the effect of the financial crisis on venture capital financing? Empirical evidence from US internet start-ups. Venture Capital: An International Journal of Entrepreneurial Finance, 11(4), 295-309. https://doi.org/10.1080/13691060903184803

Bocken, N. M. P. (2015). Sustainable venture capital - Catalyst for sustainable startup success? Journal of Cleaner Production, 108(Part A), 647-658. https:// doi.org/10.1016/j.jclepro.2015.05.079

Bottazzi, L., \& Rin, M. D. (2002). Venture capital in Europe and the financing of innovative companies. Economic Policy, 17(34), 229-270. https://doi. org/10.1111/1468-0327.00088

Bürer, M. J., \& Wüstenhagen, R. (2009). Which renewable energy policy is a venture capitalist's best friend? Empirical evidence from a survey of international 
cleantech investors. Energy Policy, 37, 4997-5006. https://doi.org/10.1016/j. enpol.2009.06.071

Cowling, M., Liu, W., Minniti, M., \& Zhang, N. (2016). UK credit and discouragement during the GFC. Small Business Economics, 47(4), 1049-1074. https:// doi.org/10.1007/s11187-016-9745-6

Creswell, J. W., \& Clark, V. L. P. (2010). Designing and conducting mixed methods research. Thousand Oaks: SAGE.

Criscuolo, C., \& Menon, C. (2015). Environmental policies and risk finance in the green sector: Cross-country evidence. Energy Policy, 83, 38-56. https:// doi.org/10.1016/j.enpol.2015.03.023

Cumming, D. (2011). Public policy and the creation of active venture capital markets. Venture Capital, 13(1), 75-94. https://doi.org/10.1080/13691066.2010.492989

Da Rin, M., Nicodano, G., \& Sembenelli, A. (2006). Public policy and the creation of active venture capital markets. Journal of Public Economics, 90(8-9), 1699-1723. https://doi.org/10.1016/j.jpubeco.2005.09.013

Demirel, P., \& Parris, S. (2015). Access to finance for innovators in the UK's environmental sector. Technology Analysis \& Strategic Management, 27(7), 782-808. https://doi.org/10.1080/09537325.2015.1019849

Dosi, G. (1990). Finance, innovation and industrial change. Journal of Economic Behavior \& Organization, 13(3), 299-319. https://doi.org/10.1016/01672681(90)90003-V

Edquist, C., \& Zabala-Iturriagagoitia, J. M. (2012). Public procurement for innovation as mission-oriented innovation policy. Research Policy, 4l(10), 1757-1769. https://doi.org/10.1016/j.respol.2012.04.022

Fischer, C., \& Newell, R. G. (2008). Environmental and technology policies for climate mitigation. Journal of Environmental Economics and Management, 55 (2), 142-162. https://doi.org/10.1016/j.jeem.2007.11.001

Foxon, T. J., \& Pearson, P. (2008). Overcoming barriers to innovation and diffusion of cleaner technologies: Some features of a sustainable innovation policy regime. Journal of Cleaner Production, 16(1), 148-161. https://doi.org/10.1016/ j.jclepro.2007.10.011

Franke, N., Gruber, M., Harhoff, D., \& Henkel, J. (2006). What you are is what you like-Similarity biases in venture capitalists' evaluations of start-up teams. Journal of Business Venturing, 21(6), 802-826.

Fricke, D. (2016). Has the banking system become more homogeneous? Evidence from banks' loan portfolios. Economics Letters, 142, 45-48. https://doi.org /10.1016/j.econlet.2016.02.024

Georgallis, P. (Panikos), \& Durand, R. (2017). Achieving high growth in policydependent industries: Differences between startups and corporate-backed ventures. Long Range Planning, 50(4), 487-500. https://doi.org/10.1016/j.1 rp.2016.06.005 
Ghosh, S., \& Nanda, R. (2010). Venture capital investment in the clean energy sector (SSRN Scholarly Paper No. ID 1669445). Rochester: Social Science Research Network. Retrieved from http://papers.ssrn.com/abstract $=1669445$

Gompers, P. A., \& Lerner, J. (2001). The venture capital revolution. The Journal of Economic Perspectives, 15(2), 145-168.

Haley, U. C. V., \& Schuler, D. A. (2011). Government policy and firm strategy in the solar photovoltaic industry. California Management Review, 54(1), 17-38. https:// doi.org/10.1525/cmr.2011.54.1.17

Henriot, A. (2013). Financing investment in the European electricity transmission network: Consequences on long-term sustainability of the TSOs financial structure. Energy Policy, 62, 821-829. https://doi.org/10.1016/j.enpol.2013.07.011

Hockerts, K., \& Wüstenhagen, R. (2010). Greening Goliaths versus emerging Davids - Theorizing about the role of incumbents and new entrants in sustainable entrepreneurship. Journal of Business Venturing, 25(5), 481-492. https:// doi.org/10.1016/j.jbusvent.2009.07.005

Hoppmann, J., Peters, M., Schneider, M., \& Hoffmann, V. H. (2013). The two faces of market support-How deployment policies affect technological exploration and exploitation in the solar photovoltaic industry. Research Policy, 42(4), 989-1003. https://doi.org/10.1016/j.respol.2013.01.002

IEA. (2016). World energy investment outlook. Paris: International Energy Agency. Retrieved from https://www.iea.org/newsroom/news/2016/september/worldenergy-investment-2016.html

Iyer, G., Hultman, N., Eom, J., McJeon, H., Patel, P., \& Clarke, L. (2015). Diffusion of low-carbon technologies and the feasibility of long-term climate targets. Technological Forecasting and Social Change, 90(Part A), 103-118. https:// doi.org/10.1016/j.techfore.2013.08.025

Jaffe, A. B., \& Lerner, J. (2011). Innovation and its discontents: How our broken patent system is endangering innovation and progress, and what to do about it. Princeton: Princeton University Press.

Jefferson, M. (2008). Accelerating the transition to sustainable energy systems. Energy Policy, 36(11), 4116-4125. https://doi.org/10.1016/j.enpol.2008.06.020

Jick, T. D. (1979). Mixing qualitative and quantitative methods: Triangulation in action. Administrative Science Quarterly, 24(4), 602-611. https://doi.o $\mathrm{rg} / 10.2307 / 2392366$

Kenney, M., \& Hargadon, A. (2012). Misguided policy? California Management Review, 54(2), 118-139. https://doi.org/10.1525/cmr.2012.54.2.118

Kenney, M., \& Hargadon, A. (2014). Venture capital and clean technology. In M. Huberty \& J. Zysman (Eds.), Can green sustain growth? From the rhetoric to the reality of sustainable prosperity. Stanford: Stanford University Press.

Keuschnigg, C., \& Nielsen, S. B. (2003). Tax policy, venture capital, and entrepreneurship. Journal of Public Economics, 87(1), 175-203. https://doi.org/10.1016/ S0047-2727(01)00170-0 
Keuschnigg, C., \& Nielsen, S. B. (2006). Public policy, start-up entrepreneurship and the market for venture capital. In S. Parker (Ed.), The life cycle of entrepreneurial ventures, International handbook series on entrepreneurship (Vol. 3, pp. 227-257). New York: Springer.

Lerner, J. (2002). When bureaucrats meet entrepreneurs: The design of effective 'public venture capital' programmes. The Economic Journal, 112(477), F73-F84. https://doi.org/10.1111/1468-0297.00684

Lerner, J. (2009). Boulevard of broken dreams: Why public efforts to boost entrepreneurship and venture capital have failed - And what to do about it. Princeton: Princeton University Press.

Lerner, J. (2010). The future of public efforts to boost entrepreneurship and venture capital. Small Business Economics, 35(3), 255-264. https://doi.org/10.1007/ s11187-010-9298-z

Lerner, J., \& Tåg, J. (2013). Institutions and venture capital. Industrial and Corporate Change, 22(1), 153-182. https://doi.org/10.1093/icc/dts050

Marcus, A., Malen, J., \& Ellis, S. (2013). The promise and pitfalls of venture capital as an asset class for clean energy investment research questions for organization and natural environment scholars. Organization \& Environment, 26(1), 31-60. https://doi.org/10.1177/1086026612474956

Mathews, J. A., Kidney, S., Mallon, K., \& Hughes, M. (2010). Mobilizing private finance to drive an energy industrial revolution. Energy Policy, 38(7), 3263-3265. https://doi.org/10.1016/j.enpol.2010.02.030

Mazzucato, M. (2013a). Financing innovation: Creative destruction vs. destructive creation. Industrial and Corporate Change, 22(4), 851-867.

Mazzucato, M. (2013b). The entrepreneurial state: Debunking public vs. private sector myths. London: Anthem Press.

Mazzucato, M. (2016). From market fixing to market-creating: A new framework for innovation policy. Industry and Innovation, 23(2), 140-156. https://doi.org $/ 10.1080 / 13662716.2016 .1146124$

Mazzucato, M., \& Penna, C. (2016). Beyond market failures: The market creating and shaping role of state investment banks. Journal of Economic Policy Reform, $19(4), 305-326$.

Migendt, M., Polzin, F., Schock, F., Täube, F. A., \& von Flotow, P. (2017). Beyond venture capital: An exploratory study of the finance-innovation-policy nexus in cleantech. Industrial and Corporate Change. https://doi.org/10.1093/icc/ dtx014

Moran-Ellis, J., Alexander, V. D., Cronin, A., Dickinson, M., Fielding, J., Sleney, J., \& Thomas, H. (2006). Triangulation and integration: Processes, claims and implications. Qualitative Research, 6(1), 45-59. https://doi. org/10.1177/1468794106058870

Negro, S. O., Alkemade, F., \& Hekkert, M. P. (2012). Why does renewable energy diffuse so slowly? A review of innovation system problems. Renewable and 
Sustainable Energy Reviews, 16(6), 3836-3846. https://doi.org/10.1016/j.rse r.2012.03.043

New Climate Economy. (2014). Better growth better climate - Charting a new path for low-carbon growth and a safer climate. Washington, DC: World Resources Institute. Retrieved from http://newclimateeconomy.report/

Nightingale, P., Murray, G., Cowling, M., Baden-Fuller, C., Mason, C., Siepel, J., et al. (2009). From funding gaps to thin markets: UK government support for early-stage venture capital. London: Nesta.

O'Sullivan, M. (2006). Finance and innovation. In J. Fagerberg, D. C. Mowery, \& R. R. Nelson (Eds.), The Oxford handbook of innovation (pp. 240-265). Oxford: Oxford University Press.

Olmos, L., Ruester, S., \& Liong, S.-J. (2012). On the selection of financing instruments to push the development of new technologies: Application to clean energy technologies. Energy Policy, 43, 252-266. https://doi.org/10.1016/j. enpol.2012.01.001

Patton, M. Q. (2002). Qualitative research and evaluation methods. Thousand Oaks: SAGE.

Perez, C. (2002). Technological revolutions and financial capital: The dynamics of bubbles and golden ages. Cheltenham: Edward Elgar Publishing.

Perez, C. (2013). Unleashing a golden age after the financial collapse: Drawing lessons from history. Environmental Innovation and Societal Transitions, 6, 9-23. https://doi.org/10.1016/j.eist.2012.12.004

Polzin, F. (2017). Mobilizing private finance for low-carbon innovation - A systematic review of barriers and solutions. Renewable and Sustainable Energy Reviews, 77, 525-535. https://doi.org/10.1016/j.rser.2017.04.007

Polzin, F., Migendt, M., Täube, F. A., \& von Flotow, P. (2015). Public policy influence on renewable energy investments-A panel data study across OECD countries. Energy Policy, 80, 98-111. https://doi.org/10.1016/j.enpol.2015.01.026

Polzin, F., von Flotow, P., \& Klerkx, L. (2016). Addressing barriers to eco-innovation: Exploring the finance mobilisation functions of institutional innovation intermediaries. Technological Forecasting and Social Change, 103, 34-46. https://doi.org/10.1016/j.techfore.2015.10.001

Polzin, F., Sanders, M., \& Täube, F. (2017a). A diverse and resilient financial system for investments in the energy transition. Current Opinion in Environmental Sustainability, 28, 24-32. https://doi.org/10.1016/j.cosust.2017.07.004

Polzin, F., Sanders, M., \& Stavlöt, U. (2017b). Do investors and entrepreneurs match? - Evidence from The Netherlands and Sweden. Technological Forecasting and Social Change. https://doi.org/10.1016/j.techfore.2017.07.016

Porter, M. E. (1991). Towards a dynamic theory of strategy. Strategic Management Journal, 12, 95-117.

Porter, M. E., \& van der Linde, C. (1995). Green and competitive: Ending the stalemate. Harvard Business Review, 73(5), 120-134. 
Rogge, K. S., \& Reichardt, K. (2016). Policy mixes for sustainability transitions: An extended concept and framework for analysis. Research Policy, 45(8), 1620-1635. https://doi.org/10.1016/j.respol.2016.04.004

Ruef, M., Aldrich, H. E., \& Carter, N. M. (2003). The structure of founding teams: Homophily, strong ties, and isolation among U.S. entrepreneurs. American Sociological Review, 68(2), 195-222. https://doi.org/10.2307/1519766

Schumpeter, J. A. (1934). The theory of economic development. Boston: Harvard University Press.

Seawright, J., \& Gerring, J. (2008). Case selection techniques in case study research. Political Research Quarterly, 61(2), 294-308. https://doi.o $\mathrm{rg} / 10.1177 / 1065912907313077$

Shepherd, D. A., \& Patzelt, H. (2011). The new field of sustainable entrepreneurship: Studying entrepreneurial action linking 'what is to be sustained' with 'what is to be developed'. Entrepreneurship Theory and Practice, 35(1), 137-163. https:// doi.org/10.1111/j.1540-6520.2010.00426.x

Szabó, S., \& Jäger-Waldau, A. (2008). More competition: Threat or chance for financing renewable electricity? Energy Policy, 36(4), 1436-1447. https:// doi.org/10.1016/j.enpol.2007.12.020

Tan, N. (2016). Global Pension Assets Study 2016. London: Willis Towers Watson. Retrieved from https://www.willistowerswatson.com/DownloadMedia.aspx? media $=\% 7 B 9 F F 7 A 5 F A-C 2 E 8-419 F-9 A 80-149 D F D E 03218 \% 7 D$

Veugelers, R. (2012). Which policy instruments to induce clean innovating? Research Policy, 41(10), 1770-1778. https://doi.org/10.1016/j.respol.2012.06.012

Weber, K. M., \& Rohracher, H. (2012). Legitimizing research, technology and innovation policies for transformative change: Combining insights from innovation systems and multi-level perspective in a comprehensive 'failures' framework. Research Policy, 41(6), 1037-1047. https://doi.org/10.1016/j.respol.2011.10.015

Wüstenhagen, R., \& Menichetti, E. (2012). Strategic choices for renewable energy investment: Conceptual framework and opportunities for further research. Energy Policy, 40, 1-10. https://doi.org/10.1016/j.enpol.2011.06.050 